\title{
Basal metabolism in women with obesity and anorexia nervosa
}

\author{
By H. LJUNGGREN, D. IKKOS AND R. LUFT \\ Department of Endocrinology and Metabolism, Karolinska Sjukhuset, Stockholm
}

(Received 30 March 1960-Revised 5 September 1960)

The results of measurements of basal metabolic rate in patients with obesity and anorexia nervosa have suggested that the basal metabolic activity of cell mass is altered in these diseases. It has been shown repeatedly that basal metabolism, expressed as oxygen consumption per unit of time, is high in obesity and low in anorexia nervosa. When the oxygen consumption per unit of time is referred to the usual reference variable, the body surface area, the values remain low for anorexia nervosa but become normal for obese patients. Since it was earlier thought that body-weight increase in obesity depended on a gain in pure fat, i.e. the metabolically inactive depot substance in fat tissue, it was concluded that obesity is accompanied by hypermetabolism.

The adequacy of the body surface area as a reference variable for the expression of the basal metabolism has been questioned repeatedly. This question became of current interest during the last decade with the introduction of in vivo 'chemical dissection' (Edelman, Olney, James, Brooks \& Moore, 1952) and the measurement of the density of the body (Behnke, Osserman \& Welham, r953) which permitted the determination of different parameters for the metabolically active part of the body in living human subjects, cell mass or lean body mass. Different authors have suggested that lean body mass or cell mass a priori should be considered as more adequate reference variables for basal metabolism than surface area.

Studies of body composition in patients with anorexia nervosa demonstrated the loss of large quantities of cell mass. Furthermore, such studies showed that, contrary to previous opinion, there occurs in obesity an increase not only in metabolically inactive depot fat but also in cell mass. These latter observations suggested that the changes in basal metabolism in patients with obesity and anorexia nervosa might be 'physiological', due to quantitative changes in cell mass, and that they are not due to hyper- or hypo-metabolism. In the present work basal metabolism and body composition were estimated in patients with obesity and anorexia nervosa as well as in a group of healthy women. The relations between basal metabolism and different parameters of cell mass were compared between the different groups of subjects. The results showed that the basal metabolic activity did not differ in these three groups, since the basal metabolism was of the same magnitude when the cell mass was used as a basis of comparison.

\section{EXPERIMENTAL}

Subjects and procedure. Body size, body-water compartments, body potassium and basal oxygen consumption were measured in sixteen healthy women, in thirteen female patients with simple obesity, and in seven typical cases of anorexia nervosa without 
complications. In one of the last patients these measurements were performed repeatedly during a period of $4 \frac{1}{2}$ months, when the body-weight increased from $27.8 \mathrm{~kg}$ initially to a maximum of $36.0 \mathrm{~kg}$ and thereafter decreased again to $32.9 \mathrm{~kg}$. None of the patients showed signs of cardiac insufficiency, disturbances of water and electrolyte metabolism or abnormal thyroid function. Their ages, body-weights and heights are shown in Table $\mathrm{x}$.

The complete series of determinations was performed usually within I week and always within 2 weeks.

The results of the measurements of body fluids and body $\mathrm{K}$ in all these subjects except no. 55 have been presented earlier in reports from this laboratory in connexion with problems of body composition (Ljunggren, Ikkos \& Luft, I957a-c). On the other hand, cases presented on previous occasions but not in the present paper are such for which measurements of basal metabolism were not available. In order to avoid confusion the numbering of the subjects in this paper is the same as in the previous ones.

Estimation of basal metabolism, body water and body $K$. Basal metabolism was measured under the usual conditions by indirect calorimetry. Pulmonary ventilation was measured in two 5 -min periods by a Tissot spirometer. Gas analysis was done in a modified Haldane apparatus, separately for each period in most instances. No training runs were used. Normal values for basal metabolism were calculated from the values for age, height and body-weight by the method of Harris \& Benedict (I919).

Body composition was estimated from the values for total body water, extracellular and intracellular water, body solids and body $\mathrm{K}$. Total body water was measured as the volume of distribution of deuterium oxide (Ljunggren, I955). Extracellular water was estimated as the 'corrected' volume of distribution of thiosulphate from which the volume of distribution of inulin is estimated (Ikkos, Ljunggren, Luft \& Sjögren, I956). Body $\mathrm{K}$ was measured as 'exchangeable' $\mathrm{K}$ with ${ }^{42} \mathrm{~K}$ by the method of Corsa, Olney, Steenburg, Ball \& Moore (I950).

Intracellular water was taken as the difference between total body water and extracellular water. Body solids were taken as the difference between body-weight and total body water.

Lean body mass was calculated as total body water $\div 0.72$ and cell mass as intracellular water $\div 0.70$, since the water content of lean body mass is taken as $72 \%$ (McCance \& Widdowson, I95 I ; Behnke et al. I953) and intracellular water is supposed to make up $67-70 \%$ of cell mass (McCance \& Widdowson, I95 I Behnke et al. 1953; Keys \& Brožek, r953).

The different body constituents are accordingly thus defined:

Total body water = deuterium space,

Extracellular water $=$ thiosulphate space ('corrected'),

Intracellular water $=$ deuterium space - thiosulphate space,

Body solids = body-weight - body water,

Body potassium = exchangeable potassium,

Lean body mass $=$ total body water $\div 0.72$,

Cell mass $=$ intracellular water $\div 0.70$. 
RESULTS

The results of the different measurements in the three groups are presented in Table I.

The mean age was 24 years for the healthy subjects and 33 and 26 years for the groups of obese and anorexic patients, respectively. It is assumed that these small differences in mean age between the groups are of no significance for the results of the study. The mean heights were almost identical, $\mathrm{I} \cdot 67, \mathrm{r} \cdot 66$ and $\mathrm{I} \cdot 65 \mathrm{~m}$ for the three groups.

The mean basal metabolic rates, as percentages of normal values estimated from age, height and weight, were $94.9,96 \cdot 0$ and $77.4 \%$ for the normal, obese and anorexic patients, respectively.

Table I. Body size, body fuids, body potassium and basal metabolism in sixteen healthy women, thirteen women with obesity and seven women with anorexia nervosa

\begin{tabular}{|c|c|c|c|c|c|c|c|c|}
\hline $\begin{array}{l}\text { Group of } \\
\text { women }\end{array}$ & $\begin{array}{c}\text { Subject } \\
\text { no. }\end{array}$ & $\begin{array}{c}\text { Age } \\
\text { (years) }\end{array}$ & $\begin{array}{l}\text { Height } \\
\text { (m) }\end{array}$ & $\begin{array}{c}\text { Weight } \\
\text { (kg) }\end{array}$ & $\begin{array}{c}\text { Total } \\
\text { body } \\
\text { water } \\
(1 .)\end{array}$ & $\begin{array}{c}\text { Extra- } \\
\text { cellular } \\
\text { water } \\
\text { (1.) }\end{array}$ & $\begin{array}{c}\text { Body K } \\
\text { (equiv.) }\end{array}$ & $\begin{array}{c}\text { Basal } \\
\text { oxygen } \\
\text { consump- } \\
\text { tion } \\
(\mathrm{ml} / \mathrm{min})\end{array}$ \\
\hline \multirow[t]{16}{*}{ Healthy } & 16 & 26 & $I \cdot 73$ & $87 \cdot 5$ & $37 \cdot 5$ & I I 8 & $2 \cdot 85$ & 225 \\
\hline & I7 & 25 & 1.70 & $72 \cdot 1$ & $36 \cdot 8$ & 10.5 & $2 \cdot 50$ & 236 \\
\hline & 18 & 24 & $r \cdot 69$ & $71 \cdot 0$ & $35 \cdot 7$ & $10 \cdot 6$ & $2 \cdot 45$ & I9I \\
\hline & 19 & 23 & $\mathrm{I} \cdot 59$ & $77^{\circ} \circ$ & 30.7 & $9 \cdot 3$ & $2 \cdot 45$ & 215 \\
\hline & 20 & 24 & $1 \cdot 70$ & $66 \cdot 0$ & $3 I \cdot 5$ & $9^{\circ} \circ$ & $2 \cdot 40$ & 201 \\
\hline & $2 r$ & 23 & $I \cdot 69$ & $65 \cdot 7$ & $32 \cdot 0$ & 10.0 & $2 \cdot 65$ & 200 \\
\hline & 22 & 22 & $I \cdot 64$ & $66 \cdot 8$ & $30 \cdot 1$ & $9 \cdot 3$ & $2 \cdot 25$ & I 84 \\
\hline & 23 & 20 & $x \cdot 70$ & $65 \cdot I$ & $29 \cdot 2$ & $8 \cdot 8$ & $2 \cdot 05$ & r 85 \\
\hline & 24 & 27 & $I \cdot 73$ & $62 \cdot 3$ & $35^{\circ} 0$ & $9 \cdot 0$ & $2 \cdot 50$ & 205 \\
\hline & 25 & 28 & $I .65$ & $64 \cdot 0$ & 32.7 & $9 \cdot 4$ & $2 \cdot 40$ & $2 \times 5$ \\
\hline & 26 & 20 & $I \cdot 73$ & $58 \cdot 5$ & $33 \cdot 6$ & $9 \cdot 8$ & $2 \cdot 70$ & 207 \\
\hline & 27 & 32 & $x \cdot 67$ & $6 I \cdot 7$ & $33 \cdot 7$ & 9.0 & $2 \cdot 30$ & 202 \\
\hline & 28 & 25 & $x \cdot 63$ & 63.5 & 29.5 & $8 \cdot 6$ & 2.55 & 186 \\
\hline & 29 & 23 & $I \cdot 65$ & $6 r \cdot 0$ & $32 \cdot 3$ & $9 \cdot 5$ & $2 \cdot 60$ & 172 \\
\hline & 30 & 23 & I.59 & $56 \cdot 5$ & $3 I \cdot 8$ & 9.7 & $2 \cdot 25$ & 198 \\
\hline & $3 I$ & 22 & $\mathrm{I} \cdot 55$ & $53^{\circ} 0$ & $28 \cdot 8$ & $7 \cdot 9$ & $2 \cdot 30$ & 163 \\
\hline \multirow[t]{13}{*}{ Obese } & 33 & 54 & $1 \cdot 68$ & $13 I \cdot 6$ & $44 \cdot 2$ & 14.4 & $2 \cdot 90$ & 294 \\
\hline & 35 & 20 & $I \cdot 77$ & I $12 \cdot 5$ & $42 \cdot 5$ & $12 \cdot 8$ & $3 \cdot 45$ & $25 \mathrm{I}$ \\
\hline & 37 & 36 & $1 \cdot 57$ & $1320^{\circ}$ & 46.0 & $12 \cdot 8$ & $3 \cdot 20$ & 312 \\
\hline & $3^{8}$ & 27 & $\mathrm{I} \cdot 67$ & $\times 16.0$ & $45^{\circ} 6$ & $13 \cdot 3$ & - & 245 \\
\hline & 39 & 25 & $I \cdot 73$ & $I \pm 0.5$ & $38 \cdot 9$ & $12 \cdot 6$ & $2 \cdot 90$ & $25^{\circ}$ \\
\hline & 40 & $4 I$ & $x \cdot 79$ & $1010^{\circ}$ & $46 \cdot 3$ & $11 \cdot 6$ & - & 232 \\
\hline & $4 I$ & 42 & I. 57 & $12 \mathrm{I} \cdot 5$ & $47 \cdot 9$ & 15.0 & - & 269 \\
\hline & 42 & 42 & 1.69 & 100.5 & 39.5 & $1 \mathrm{I} \cdot 8$ & $2 \cdot 85$ & 217 \\
\hline & 43 & $4^{8}$ & $1 \cdot 63$ & $107^{\circ} 0$ & $45^{\circ} 3$ & $13 \cdot 3$ & - & 288 \\
\hline & 44 & $2 I$ & 1.66 & $102 \cdot 3$ & $41 \cdot 9$ & $11 \cdot 3$ & $3 \cdot 10$ & 227 \\
\hline & 46 & 20 & $\mathrm{I} \cdot 67$ & $98 \cdot 4$ & $40 \cdot I$ & 13.0 & - & 255 \\
\hline & 47 & 23 & $I \cdot 6 I$ & $97^{\circ} \mathrm{I}$ & $39^{\circ} \mathrm{I}$ & II $\cdot 0$ & 一 & 250 \\
\hline & 48 & 28 & $I \cdot 59$ & $88 \cdot 3$ & $34^{\cdot I}$ & 10.5 & $3 \cdot 10$ & 210 \\
\hline \multirow[t]{7}{*}{ Anorexic } & 50 & 24 & $x \cdot 73$ & $4 r \cdot 2$ & $27 \cdot 0$ & $9 \cdot 2$ & $1 \cdot 85$ & 130 \\
\hline & 51 & 23 & $1 \cdot 65$ & $45^{\circ} 5$ & $28 \cdot 9$ & 8.9 & 2.00 & I 57 \\
\hline & 52 & I9 & $I \cdot 64$ & $44^{\circ} 5$ & $22 \cdot 8$ & $7 \cdot 2$ & $1 \cdot 70$ & 164 \\
\hline & 54 & 37 & I.59 & $42 \cdot 4$ & $25^{.2}$ & $8 \cdot 5$ & $1 \cdot 95$ & 146 \\
\hline & 55 & 20 & $1 \cdot 73$ & $38 \cdot 9$ & $25 \cdot 7$ & 8.8 & $1 \cdot 90$ & 132 \\
\hline & 56 & 29 & $1 \cdot 62$ & $39^{\circ} 8$ & $25 \cdot 4$ & $7 \cdot 3$ & $1+90$ & I34 \\
\hline & $5^{8}$ & 33 & $I \cdot 60$ & $27 \cdot 8$ & $17 \cdot 7$ & 5.5 & $I \cdot 30$ & 82 \\
\hline
\end{tabular}


The mean values for body size, body constituents and basal metabolism are shown in Table 2. The large differences in weight between the groups were accompanied by similar significant differences in all other measurements. The values were larger for the obese group than for the normal, and the values for it in turn larger than for the anorexic group.

Table 2. Mean values with their standard errors for body size, body fluids, body potassium and basal metabolism in the three groups of women and differences between the groups of obese and normal women and the groups of normal and anorexic women, respectively

\begin{tabular}{|c|c|c|c|c|c|}
\hline \multirow[b]{3}{*}{ Measurement } & \multirow{2}{*}{\multicolumn{3}{|c|}{ Group means }} & \multicolumn{2}{|c|}{ Differences of means* } \\
\hline & & & & Nomel & \\
\hline & Anorexic & Normal & Obese & anorexic & normal \\
\hline No. of subjects & 7 & 16 & 13 & & \\
\hline Weight (kg) & $\pm 2 \cdot 2$ & $\pm 2 \cdot 1$ & $\pm 3 \cdot 7$ & \pm 3.4 & $\pm 4 \cdot 2$ \\
\hline Total body water (1.) & $\pm I \cdot 4$ & \pm 0.7 & $\pm I \cdot I$ & $\pm \mathrm{I} \cdot 5$ & $\pm I \cdot 3$ \\
\hline Extracellular water (1.) & $7 \cdot 9 \pm 0.5$ & $9.5 \pm 0.2$ & I2.6 \pm 0.4 & $I .6 \pm 0.6$ & $3.1 \pm 0.5$ \\
\hline Intracellular water (1.) & $16.8 \pm 0.9$ & $23.0 \pm 0.5$ & $29.8 \pm 0.9$ & $6 \cdot 2 \pm I \cdot 4$ & $6 \cdot 9 \pm 1 \cdot 0$ \\
\hline Body solids (kg) & I $5 \quad \pm I \cdot 4$ & $33 \pm \mathrm{I} \cdot 8$ & $67 \pm 3 \cdot 0$ & $18 \pm 2 \cdot 3$ & $34 \pm 3.5$ \\
\hline Body K (equiv.) & $1.80 \pm 0.09$ & $2.45 \pm 0.05$ & $3.07 \pm 0.08 \dagger$ & $0.65 \pm 0.10$ & $0.62 \pm 0.09$ \\
\hline $\begin{array}{l}\text { Basal oxygen consump- } \\
\text { tion }(\mathrm{ml} / \mathrm{min})\end{array}$ & $135 \pm 5$ & $199 \pm 5$ & $254 \pm 8$ & $64 \pm 7$ & $55 \pm 10$ \\
\hline
\end{tabular}

Table 3. Results of regression analyses of basal oxygen consumption of healthy women, women with obesity and women wth anorexia nervosa on various independent variables

\begin{tabular}{|c|c|c|c|c|c|c|c|}
\hline \multirow[b]{3}{*}{$\begin{array}{l}\text { Independent } \\
\text { variable }\end{array}$} & & & & \multicolumn{4}{|c|}{$\begin{array}{c}\text { Significance of differences between } \\
\text { regressions }\end{array}$} \\
\hline & \multicolumn{3}{|c|}{ Significance of regressions } & \multicolumn{2}{|c|}{ Anorexic-normal } & \multicolumn{2}{|c|}{ Obese-normal } \\
\hline & Anorexic & Normal & Obese & Slopes & $\begin{array}{l}\text { Mean } \\
\text { levels }\end{array}$ & Slones & Mean \\
\hline $\begin{array}{l}\text { Total body } \\
\text { water }\end{array}$ & $*$ & ** & * & NS & NS & NS & NS \\
\hline $\begin{array}{l}\text { Intracellular } \\
\text { water }\end{array}$ & $*$ & $* *$ & NS & NS & NS & NS & NS \\
\hline Body potassium & * & NS & NS & NS & NS & - & - \\
\hline Height & NS & NS & NS & - & - & - & - \\
\hline Weight & $* * *$ & * & $* * *$ & ** & - & NS & NS \\
\hline $\begin{array}{l}\text { Extracellular } \\
\text { water }\end{array}$ & NS & ** & ** & NS & $* *$ & NS & NS \\
\hline Body solids & $* * *$ & NS & $* *$ & * & - & NS & NS \\
\hline
\end{tabular}

-, Test not applicable; NS, not significant, $0.05<P$. *, Significant, $0.01<P \leqslant 0.05 .{ }^{* *}$, Significant, $0.001<P \leqslant 0.01$. ***, Significant, $P \leqslant 0.001$.

The relations between basal oxygen consumption and the values for body size and body constituents were examined by regression analysis. In each of the three groups of subjects the regression equations for basal metabolism on body-weight, water compartments, body solids and $\mathbf{K}$ were calculated separately, with basal metabolism as the dependent variable, a straight-line relationship between the variables examined being assumed. Table 3 shows the statistical significance of each of these regressions and also 
shows where they differed significantly between groups, either in slope or, when the slopes were the same, in the mean level of oxygen consumption for any given value of the independent variable.

Table 3 shows that in relation to total body water, intracellular water or body $\mathrm{K}$ there was no significant difference in basal oxygen consumption between the anorexic patients and the normal women, but that there were significant differences when weight, extracellular water or body solids was taken as the basis of comparison. No significant differences in basal oxygen consumption were found between the obese and the normal women whichever of these six measurements was taken as the basis of comparison.

Table 4. Composition and metabolic activity of the tissues accounting for the differences in weight between the groups of obese and healthy women and of healthy and anorexic women, respectively

Constituent

Total water (\%)

Extracellular water (\%)

Intracellular water (\%)

Solids (\%)

Potassium (m-equiv./kg)

Oxygen consumption ( $\mathrm{ml} / \mathrm{min} \mathrm{kg}$ )
Obese-normal Normal-anorexic

$\begin{array}{rr}22 \cdot 7 & 32 \cdot 3 \\ 7 \cdot 0 & 7 \cdot 2 \\ 15 \cdot 7 & 25 \cdot 1 \\ 77 \cdot 3 & 67 \cdot 7 \\ 13 \cdot 7 & 28 \cdot 1 \\ 1 \cdot 3 & 2 \cdot 5\end{array}$

Table 5. Body-weight, body fuids, basal metabolism and cell mass in one woman with anorexia nervosa

\begin{tabular}{|c|c|c|c|c|c|c|}
\hline $\begin{array}{l}\text { Day of } \\
\text { study }\end{array}$ & $\begin{array}{c}\text { Weight } \\
\text { (kg) }\end{array}$ & $\begin{array}{c}\text { Total } \\
\text { body } \\
\text { water } \\
(1 .)\end{array}$ & $\begin{array}{c}\text { Extracellular } \\
\text { water } \\
\text { (1.) }\end{array}$ & $\begin{array}{l}\text { Intracellular } \\
\text { water } \\
\text { (l.) }\end{array}$ & $\begin{array}{l}\text { Basal oxygen } \\
\text { consumption } \\
(\mathrm{ml} / \mathrm{min})\end{array}$ & $\begin{array}{c}\text { Cell } \\
\text { mass* } \\
(\mathrm{kg})\end{array}$ \\
\hline I & 27.8 & 17.7 & 5.5 & $12 \cdot 2$ & 82 & $17 \cdot 4$ \\
\hline 30 & $32 \cdot 5$ & $21^{\circ} 9$ & $7 \cdot 7$ & $14: 2$ & 120 & $20 \cdot 3$ \\
\hline 44 & $36 \cdot 0$ & $27^{\circ} 0$ & $8 \cdot 7$ & $18 \cdot 3$ & I 36 & $26 \cdot 1$ \\
\hline 57 & 36.0 & $24^{\circ} \mathrm{I}$ & 8.7 & 15.4 & 142 & $22 \cdot 0$ \\
\hline 87 & $34 \cdot 3$ & $2 I^{\circ} 0$ & $6 \cdot 2$ & 14.8 & 129 & $2 I \cdot I$ \\
\hline $13^{8}$ & $32 \cdot 9$ & $20: 3$ & 5.5 & 14.7 & I 2 I & $210^{\circ}$ \\
\hline
\end{tabular}

* Calculated as intracellular water $\div 0.70$.

The mean intracellular concentration of $\mathrm{K}$ in the subjects with anorexia nervosa, I08 $\pm 2 \cdot \mathrm{I}$ m-equiv./1., calculated as the mean value of the quotients between the values for body $\mathrm{K}$ and intracellular water, was not significantly different from that for the normal subjects, $106 \pm 2 \cdot 3 \mathrm{~m}$-equiv./1. A cellular deficiency of $\mathrm{K}$ could therefore not be demonstrated in our anorexic patients.

The differences in the measured variables between the obese and normal groups on the one hand and between the normal and anorexic groups on the other were calculated from the mean values in Table 2. From these differences an approximate value was obtained for the composition and 'basal metabolism' of the tissue gained in obesity and lost in anorexia nervosa, and the results are presented in Table 4. The tissue lost by the women with anorexia nervosa contained according to this approximation larger concentrations of total water, intracellular water and $\mathrm{K}$ than the tissue gained by 
the obese women. Moreover, the metabolic activity of the former, $2.5 \mathrm{ml} \mathrm{oxygen} / \mathrm{min}$ $\mathrm{kg}$, was higher than the corresponding value for the latter, $\mathrm{x} \cdot 3 \mathrm{ml} / \mathrm{min} \mathrm{kg}$.

Table 5 presents the results of the measurements in one of the women with anorexia nervosa, with whom repeated measurements were made over a period of $4 \frac{1}{2}$ months. Changes in body-weight were accompanied by parallel changes in the body water compartments and body $\mathrm{K}$, as well as in the basal metabolism.

\section{ISCUSSION}

Basal metabolism in obesity. The values obtained for basal metabolism are in accord with earlier observations. Obesity increases basal oxygen consumption (Du Bois, 1936). The high value will become normal when referred to body size, which is also increased. The basal metabolic rate is therefore normal in obesity (Boothby $\&$ Sandiford, r922).

At one time the increase in weight in obesity was explained as a gain of pure fat only. The metabolizing tissue, the cell mass, would, according to this opinion, remain unchanged. The increase in basal metabolism should therefore signify an intensification of the metabolic activity of cell mass (Evans \& Strang, I93 I; Rony, I940; Rossier, I95 I). The magnitude of this increase might be estimated if the reference values for basal metabolism were calculated from the 'ideal' instead of observed body-weights. The values obtained should then be an approximation of the normal values for the patients, i.e. the values expected in subjects of the same age, sex and height, but of normal weight. The difference between these values and the values measured would estimate the abnormal increase in basal metabolism. The increased work load of the cardiovascular and locomotor systems, which must accompany increasing obesity, has been considered as the reason for this increase in basal metabolism, which was considered to amount to $20-25 \%$ of the 'ideal' value (Evans \& Strang, I93I). The work load and the laboured breathing would preclude true basal conditions during measurements of basal metabolism (Rony, 1940; Evans, 1952; Ries, 1958). An increase in thyroid function has also been assumed (Stiller, 1954). Such an intensification of thyroid function has not been demonstrated in simple obesity, however, by means of studies with radio-iodine or from levels of protein-bound iodine in serum (Williams, I948; Starr, Petit, Chaney, Rollman, Aiken, Jamieson \& Kling, I950; Skanse \& Hedenskog, 1957).

It can now be considered an established fact that obesity is associated with an increase of cell mass, which probably corresponds to a hypertrophy of parenchymatous organs, skeletal and cardiac muscles and an increase in blood cells, which all enables the extra work to be done, and, furthermore, a cellular hyperplasia in adipose tissue. This statement is based on the results of experimental studies on animals and man. A probable new formation of fat cells has been shown by histological studies (Clark \& Clark, 1940; Reh, 1953). An increase in the fat-free parenchymatous tissues and fatfree body mass has been demonstrated in different forms of experimental obesity (Brecher \& Waxler, r949; Kennedy, 195 I; Fenton \& Dowling, I953; Drachman \& Tepperman, 1954; Babineau \& Pagé, 1955; Fenton, 1956; Pitts, 1956, I957; Marshall, 
Andrus \& Mayer, 1957) and an increase in myocardium and blood cells has been shown in man (Reiner, Mazzoleni \& Rodriguez, 1955; Huff \& Feller, 1956). An increase of cell mass has also been demonstrated in man by use of various methods for the estimation of body composition (McCance \& Widdowson, 195I; Brožek \& Keys, I955; Johnston \& Bernstein, 1955; Keys, Anderson \& Brožek, 1955; Ljunggren et al. $1957 b$; Passmore, Strong \& Ritchie, 1958; Ljunggren et al. 1959). This increase in cell mass might explain part of the nitrogen retention which accompanies increases in calorie intake (Grafe, 1923; Cuthbertson, McCutcheon \& Munro, 1937; Munro, 195I).

The present findings of larger amounts of total body water, intracellular water and body $\mathrm{K}$ in the obese than in the normal women (Table 2) are in accordance with the results of the studies mentioned above. Total body water is a parameter of lean body mass (Pace \& Rathbun, I945), and intracellular water and body $\mathrm{K}$ are parameters of cell mass (Corsa et al. 1950; McCance \& Widdowson, 195 I). Therefore, the increase in these constituents in obese women points to an increase in the absolute amounts of their cell mass.

The calculated composition of the tissue accounting for the differences in weight between the obese and the normal groups (Table 4) agrees fairly well with the composition of 'obesity tissue', arrived at by other authors with techniques different from or similar to ours (Brožek \& Keys, I955; Johnston \& Bernstein, 1955; Keys et al. 1955; Passmore et al. 1958). (See also Ljunggren et al. ( $(957 b)$ who made similar calculations for greater numbers, including the thirteen obese patients described here.)

The hypothesis that an increase in cell mass might explain the increase in basal oxygen consumption by obese subjects was put forward among others by Grafe (1923), Talbot, Wilson \& Worcester (1937) and Keys et al. (195I). The results of the regression analysis (Table 3 ) are in accord with this assumption since no differences were demonstrated between the obese and normal women in the regression of basal metabolism on either total body water, intracellular water or body $\mathrm{K}$. Consequently, it is apparent that the metabolic activity of the cell mass in the obese women is normal and that the increase in basal metabolism is a reflection of an increase in cell mass. Thus, the present findings speak against the concept of an abnormal hypermetabolism in obesity.

Basal metabolism in anorexia nervosa. The results obtained by measurements of basal metabolism in the women with anorexia nervosa are also in accord with earlier observations. A decrease of basal oxygen consumption and basal metabolic rate is a constant finding in anorexia nervosa as well as in other forms of undernutrition (Du Bois, 1936).

The finding of decreases in the parameters of cell mass (total body water, intracellular water and body $\mathrm{K}$ ) in the group of patients with anorexia nervosa (Table 2) illustrates the well-known fact that a significant breakdown not only of fat stores but also of musculature and parenchymatous organs accompanies severe malnutrition (see Keys, Brožek, Henschel, Mickelsen \& Taylor, 1950). (See also Ljunggren et al. (1957c), who made similar calculations for larger numbers including the seven anorexic women described here.)

The assumption that hypometabolism occurs in anorexia nervosa has prevailed for many years; this hypometabolism has been attributed to hypothyroidism secondary to pituitary insufficiency (Wahlberg, 1935; Mulinos \& Pomerantz, 1940; Stephens, 1941; 
Berkman, Weir \& Kepler, 1947; D’Angelo, I95 I; Rivero-Fontan, Paschkis, West \& Cantarow, 1952). Thyroid preparations have therefore been widely used in treatment of patients with anorexia nervosa. There are other observations, however, that do not agree with the assumption of such a decrease in metabolic activity. Thus, thyroid function, as studied by means of radio-iodine and plasma protein-bound iodine, has always been found normal (Peters \& Mann, 1948; Keating, Hanies, Power \& Williams, 1950; Wild, Scazziga \& Reymond, 1955; Bliss \& Migeon, 1957) and raising the basal metabolic rate by thyroid administration as a rule induced toxic symptoms.

The results of the regression analysis (Table 3 ) do not support the hypothesis that the basal metabolic activity of cell mass is changed in anorexic women. When the basal metabolism in such women was compared with that of normal women on the basis of the parameters of cell mass (total body water, intracellular water and body $\mathrm{K}$ ), no significant differences between these two groups could be demonstrated. In other words, the decrease in the absolute values for basal metabolism could be entirely accounted for by the decrease in cell mass. Therefore, the decrease in the basal metabolic rate, with body size as reference variable, does not demonstrate any change in basal metabolic activity of cell mass in patients with anorexia nervosa. The decrease depends on the fact that cell mass becomes smaller, in relation to total body size, in patients with anorexia nervosa.

The opinion that the metabolism is normal in anorexia nervosa agrees with the normal thyroid function in these patients (see above), as well as with the results obtained in patients with other forms of malnutrition. Beattie \& Herbert ( 1947 ) found a normal oxygen consumption per unit of 'active tissue' in starved prisoners of war and Venkatachalam, Scrikantia \& Gopalan (1954) found normal oxygen consumption per unit weight of cell solids in Indians with severe malnutrition. Most of the decrease in basal metabolism observed in the Minnesota experiment on starvation could be accounted for by loss of metabolically active tissue (Keys et al. 1950). It seems reasonable to conclude that basal metabolic activity of cell mass in women with anorexia nervosa does not differ from that of normal women.

Metabolic activity of cell mass and lean body mass. The conclusion that basal metabolism is normal in obesity and anorexia nervosa is based on the thesis that cell mass is a more appropriate reference standard for expressing the results of determination of basal metabolism than surface area or other measures of body size. The early view of a surface-area law, i.e. of a causal relationship between body surface area and basal metabolism has not been generally accepted. Benedict \& Talbot (1914) formulated the view that the basal metabolism is related to the 'active protoplasmic mass'. Moulton (1916) found a close interrelation in cattle between basal oxygen consumption, active protoplasmic mass and surface area. Boothby \& Sandiford (1924) suggested that the surface area derived its value as reference variable from the fact that it represented ' $a$ practical method of measuring active protoplasmic mass'. That surface area is closely correlated to the lean body mass and cell mass and that there exist high intercorrelations between surface area, lean body mass, cell mass and basal oxygen consumption has been repeatedly demonstrated in man (Steele, Brodie, Messinger, Soberman, Berger \& Galdston, I949; Miller \& Blyth, I953; Wedgwood, Bass, Klimas, Kleeman 
\& Quinn, 1953; Johnston \& Bernstein, 1955; Ikkos, 1956). Different authors have suggested the use of lean body mass or other measures of the metabolically active tissues of the body as reference variables for basal metabolism in preference to surface area (Behnke et al. 1953; Keys \& Brožek, 1953; Miller \& Blyth, 1953; Shock, 1955; Ikkos, 1956).

Regression analyses of basal metabolism on the different parameters of cell mass (total body water, intracellular water and body $\mathrm{K}$ ) showed, as mentioned above, no significant differences between the regressions for the normal women and those for the two other groups of women. On the assumption that the relationships might be taken to be the same for all three groups, the combined values were used for the calculation of single regression equations, which are given in Table 6 and Fig. I. They may be considered as estimates of the normal relationships between basal oxygen consumption and the parameters of cell mass.

Table 6. Regression equations calculated for all women, healthy, obese and anorexic, taken together in one group

Regression equation

(1) Oxygen consumption $(\mathrm{ml} / \mathrm{min})=6.14 \times$ total body water $(1)-$.

(2) Oxygen consumption $(\mathrm{ml} / \mathrm{min})=8 \cdot 17 \times$ intracellular water $(1)+.8 \cdot 1$

(3) Oxygen consumption $(\mathrm{ml} / \mathrm{min})=84^{\cdot} \mathrm{I} \times$ body potassium (equiv.) $-9 \cdot 0$

Correlation
coefficient
0.92
0.90
0.85

From these equations one may calculate the normal metabolic activity of lean body mass and cell mass. Since a change of total body water by I l. corresponds to a change of $6.14 \mathrm{ml}$ oxygen/min (equation $\mathrm{r}$, Table 6 ) and since the water content of lean body mass is taken as $72 \%$, the basal oxygen consumption of lean body mass can be calculated to be $0.72 \times 6 \cdot 1$ or $4.4 \mathrm{ml} / \mathrm{min} \mathrm{kg}$ lean body mass. Such a value is in agreement with the values reported by others, varying between 4.0 and $4.9 \mathrm{ml} / \mathrm{min} \mathrm{kg}$ (Bernstein, Johnston, Ryan, Inouye \& Hick, 1956; von Döbeln, 1956; Banerjee \& Sen, 1958).

The metabolic activity of cell mass can be estimated from the regressions on intracellular water and body $\mathrm{K}$. The coefficient for the regression on intracellular water was $8 \cdot \mathrm{I} \mathrm{ml} / \mathrm{min}$, when the variation in intracellular water is $\mathrm{I} 1$. (equation 2, Table 6). As intracellular water is supposed to make up $67-70 \%$ of cell mass, the metabolic activity of cell mass will be $0.70 \times 8 \cdot 1$ or $5.7 \mathrm{ml} / \mathrm{min} \mathrm{kg}$. This result may also be compared with those reported earlier, varying between 5.9 and $8.5 \mathrm{ml} / \mathrm{min} \mathrm{kg}$ (Bernstein et al. 1956; Ryan, Williams, Ansell \& Bernstein, 1957; Banerjee \& Sen, 1958).

The coefficient for the regression on body $\mathrm{K}$ was $84 \cdot \mathrm{I}$ (equation 3, Table 6). A change in body $\mathrm{K}$ of $\mathrm{I}$ equiv. is thus accompanied by a change in basal metabolism of $84 \mathrm{ml} / \mathrm{min}$. The intracellular $\mathrm{K}$ concentration is assumed to be $150 \mathrm{~m}$-equiv./1. (Fenn, 1936; Manery \& Hastings, 1939; Hastings, 1940-1). The K concentration of cell mass should then be $0.70 \times 150$ or $105 \mathrm{~m}$-equiv. $/ \mathrm{kg}$, if intracellular water is taken as $70 \%$ of cell mass. The second estimate of the metabolic activity of cell mass is therefore $0.105 \times 84$ or $8.8 \mathrm{ml} / \mathrm{min} \mathrm{kg}$.

The latter seems to be the more probable estimate of the metabolic activity of cell mass. Body $\mathrm{K}$ should be more reliable as parameter of cell mass than the estimated 
volumes of intracellular water. $\mathrm{K}$ is almost exclusively intracellular. The correction of the thiosulphate space implies an estimation of the volume of distribution of inulin. The thiosulphate space will therefore not include part of the extracellular water volume, for instance the 'transcellular' water (Edelman et al. 1952). The thiosulphate space is certainly smaller than the true extracellular water, and intracellular water will appear larger to a corresponding degree, when calculated as the difference between total body water and extracellular water. It is therefore probable that the value for the metabolic activity of cell mass, which was calculated from the regression on intracellular water, is smaller than the true one.

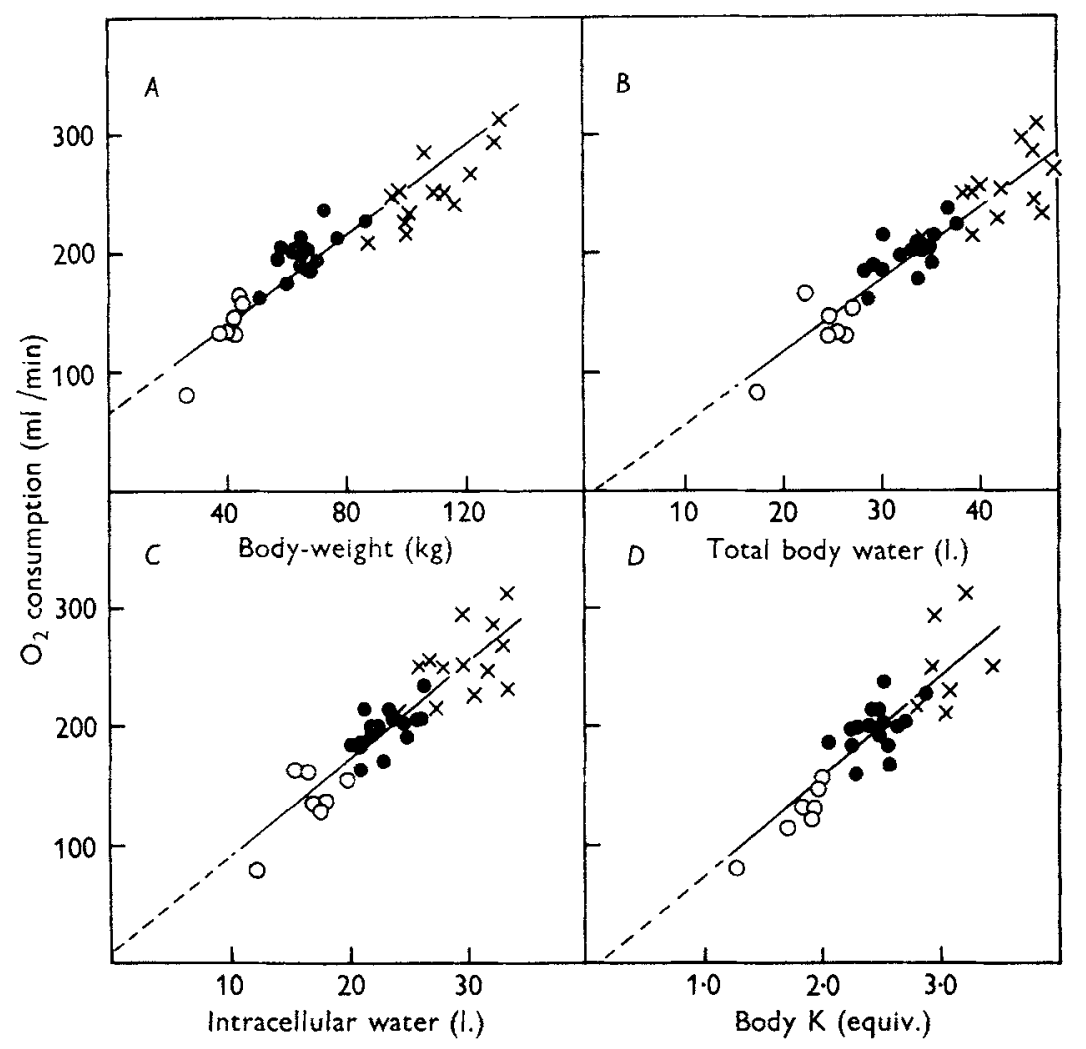

Fig. I. Regressions of basal oxygen consumption on body-weight $(A)$, total body water (lean body mass $\times 0.72)(B)$, intracellular water (cell mass $\times 0.70)(C)$ and body potassium $(D)$ for the anorexic, normal and obese women taken together. - , normal women; $x$, obese women; $O$, anorexic women. Regressions $B, C$ and $D$ go through the origin, regression $A$ does not.

If $8.5 \mathrm{ml} / \mathrm{min} \mathrm{kg}$ is taken as an approximation of the normal metabolic activity of cell mass, the value obtained for 'obesity tissue', $\mathrm{I} \cdot 3 \mathrm{ml} / \mathrm{min} \mathrm{kg}$ is of reasonable magnitude. Cell mass constitutes $20-25 \%$ of obesity tissue (Keys et al. 1955).

Finally, it has been suggested that the metabolic activity of cell mass is not constant but varies with the ratio of surface area to cell mass (Bernstein et al. 1956; Ryan et al. 1957). A high value for this ratio would signify increased heat losses through the body surface, which are then compensated for by increased heat production or an increased 
metabolic activity of cell mass. There should, accordingly, be a correlation between the ratio of basal metabolism to cell mass and the ratio of surface area to cell mass. Our results do not support this view. A correlation of statistical significance could not be demonstrated for the total group in the present study, when intracellular water was taken as parameter of cell mass and body surface was determined from body height and weight by use of the Du Bois nomogram (coefficient of correlation 0.22).

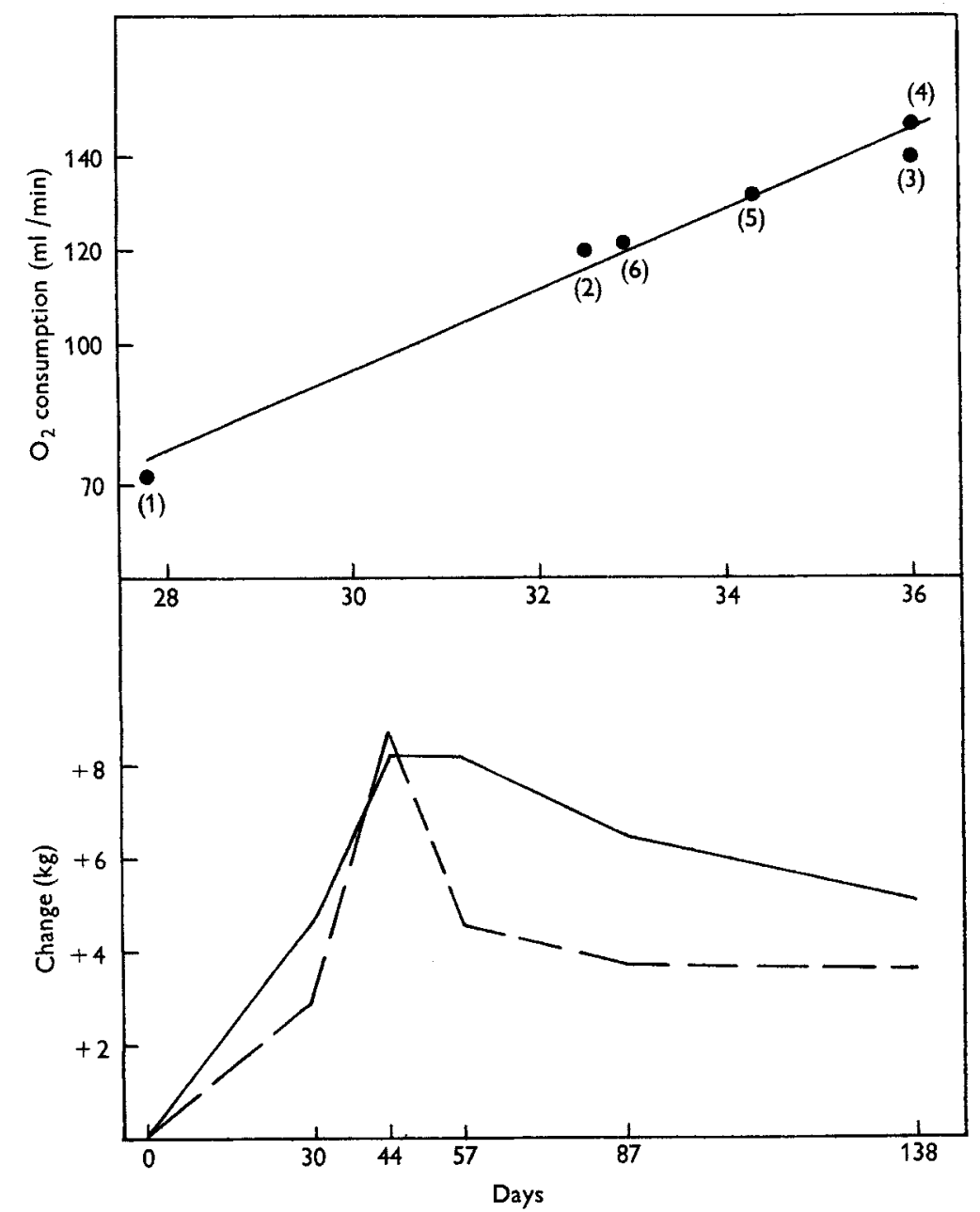

Fig. 2. Regression of basal oxygen consumption on body-weight in one woman (subject no. $5^{8}$ ) with anorexia nervosa. The simultaneous changes in body-weight and cell mass are also shown. Figures in parentheses show the order of the determinations. __, body-weight; - . . -, cell mass.

Practical application. Our results for subject no. $5^{8}$ permit a study of the relation between body-weight, basal metabolism and body composition in one of the anorexic women, who was examined repeatedly during $4 \frac{1}{2}$ months (Table 5 and Fig. 2). The correlation between the values for body-weight and basal metabolism was very high as 
is shown in Fig. 2. The following regression equation could be calculated for this relationship:

$$
\text { Oxygen consumption }(\mathrm{ml} / \mathrm{min})=6.9 \times \text { body-weight }(\mathrm{kg})-107 ; r=0.99 \text {. }
$$

The simplest explanation for this linear relationship is that the metabolic activity of the tissue gained or lost by the patient was nearly constant, and that the metabolic activity of her remaining tissues did not change as her weight changed. On this theory the regression coefficient of basal metabolism on weight provides an estimate of $6.9 \mathrm{ml} / \mathrm{min} \mathrm{kg}$ for the metabolic activity of the tissue gained or lost. It is only slightly smaller than the value, $8.5 \mathrm{ml} / \mathrm{min} \mathrm{kg}$, estimated for the metabolic activity of normal cell mass, and suggests that most of the tissue gained or lost was pure cell mass. This conclusion is in accordance with the evidence given in Table 5 and Fig. 2 that variation in cell mass may explain most of the variation in body-weight. The relative agreement between the values estimated for the metabolic activity of the tissue gained or lost by the patient and for the metabolic activity of normal cell mass gives further support to the theory that the cellular metabolic activity in patients with anorexia nervosa is normal.

\section{SUMMARY}

I. Basal metabolism, total body water, extracellular water and body potassium were determined in seventeen healthy women, thirteen female patients with obesity and seven with anorexia nervosa. Intracellular water was calculated as the difference between total body water and extracellular water. Body $\mathrm{K}$ and intracellular water were considered as parameters of cell mass.

2. From analyses of the regressions of basal metabolism on total body water, intracellular water and on body $\mathrm{K}$ for the three groups of women it was concluded that cellular metabolic activity is normal in obesity and anorexia nervosa.

3. The normal metabolic activity of cell mass could be estimated as $8.5 \mathrm{ml} / \mathrm{min} \mathrm{kg}$ and that of 'obesity tissue' as $1 \cdot 3 \mathrm{ml} / \mathrm{min} \mathrm{kg}$.

4. One of the anorexic patients was repeatedly examined during $4 \frac{1}{2}$ months, and the results suggested that the tissue lost and gained had a high metabolic activity, slightly less than that of cell mass. This finding is again in accord with the conclusion that cellular metabolic activity is normal in anorexia nervosa.

\section{REFERENCES}

Babineau, L. M. \& Pagé, E. (1955). Canad. F. Biochem. Physiol. 33, 970.

Banerjee, S. \& Sen, R. (1958). F. appl. Physiol. r2, 29.

Beattie, J. \& Herbert, P. H. (r947). Brit. F. Nutr. I, 185.

Behnke, A. R., Osserman, E. F. \& Welham, W. C. (1953). Arch. intern. Med. 9r, 585.

Benedict, F. G. \& Talbot, F. B. (1914). Publ. Carneg. Instn, no. 201.

Berkman, J. M., Weir, J. F. \& Kepler, E. J. (1947). Gastroenterology, 9, 357.

Bernstein, L. M., Johnston, L. C., Ryan, R., Inouye, J. \& Hick, F. H. (1956). F. appl. Physiol. 9, 24 ז.

Bliss, E. L. \& Migeon, C. J. (1957). F. clin. Endocrin. 17, 766.

Boothby, W. M. \& Sandiford, I. (1922). F. biol. Chem. 54, 783.

Boothby, W. M. \& Sandiford, I. (1924). Physiol. Rev. 4, 69.

Brecher, G. \& Waxler, S. H. (1949). Proc. Soc. exp. Biol., N. Y., 7o, 498. 
Brožek, J. \& Keys, A. (1955). Fed. Proc. 14, 22.

Clark, E. R. \& Clark, E. L. (1940). Amer. $\mathscr{F}$. Anat. 67, 255.

Corsa, L., Olney, J. M., Steenburg, R. W., Ball, M. R. \& Moore, F. D. (I950). F. clin. Invest. 29, I280.

Cuthbertson, D. P., McCutcheon, A. \& Munro, H. N. (I937). Biochem. F. 31, 68 r.

D'Angelo, S. A. (I95 I). Endocrinology, 48, 341.

Drachman, R. H. \& Tepperman, J. (I954). Yale F. Biol. Med. 26, 394.

Du Bois, E. F. (1936). Basal Metabolism in Health and Disease. Philadelphia: Lea and Febiger.

Edelman, I. S., Olney, J. M., James, A. H., Brooks, L. \& Moore, F. D. (1952). Science, rr5, 447.

Evans, F. A. (1952). Obesity. In Diseases of Metabolism, p. 6or. [G. G. Duncan, editor.] Philadelphia: Saunders.

Evans, F. A. \& Strang, J. M. (193 r). F. Amer. med. Ass. 97, ro63.

Fenn, W. O. (1936). Physiol. Rev. 16, 450.

Fenton, P. F. (1956). Amer. F. Physiol. 184, 52.

Fenton, P. F. \& Dowling, M. T. (1953). F. Nutr. 49, 3 r9.

Grafe, E. (1923). Ergebn. Physiol. 21, 1.

Harris, J. A. \& Benedict, F. G. (1919). Publ. Carneg. Instn, no. 279.

Hastings, A. B. (1940-I). Harvey Lect. 36, 9 1.

Huff, R. L. \& Feller, D. D. (1956). F. clin. Invest. 35, х.

Ikkos, D. (1956). Acta endocr., Copenhagen, 2x, Suppl. 25.

Ikkos, D., Ljunggren, H., Luft, R. \& Sjögren, B. (1956). Acta physiol. scand. 35, 254.

Johnston, L. C. \& Bernstein, L. M. (I955). F. Lab. clin. Med. 45, rog.

Keating, F. R., Hanies, S. F., Power, M. H. \& Williams, M. M. D. (1950). F. clin. Endocrin. Io, I 425 .

Kennedy, G. C. (195I). Proc. R. Soc. Med. 44, 899 .

Keys, A., Anderson, J. T. \& Brožek, J. (1951). Amer. F. Physiol. 167, 802.

Keys, A., Anderson, J. T. \& Brožek, J. (1955). Metabolism, 4, 427.

Keys, A. \& Brožek, J. (1953). Physiol. Rev. 33, 245.

Keys, A., Brožek, J., Henschel, A., Mickelsen, O. \& 'Taylor, H. L. (1950). The Biology of Human Starvation. Minneapolis: University of Minnesota Press.

Ljunggren, H. (1955). Acta physiol. scand. 33, 69.

Ljunggren, H., Ikkos, D. \& Luft, R. (I957a). Acta endocr., Copenhagen, 25, 187.

Ljunggren, H., Ikkos, D. \& Luft, R. (1957b). Acta endocr., Copenhagen, 25, 199.

Ljunggren, H., Ikkos, D. \& Luft, R. (I957c). Acta endocr., Copenhagen, 25, 209.

Ljunggren, H., Ikkos, D. \& Luft, R. (1959). Brit. F. Nutr. 13, 485.

McCance, R. A. \& Widdowson, E. M. (195I). Proc. roy. Soc. B, 138, 115.

Manery, J. F. \& Hastings, A. B. (1939). F. biol. Chem. 127, 657.

Marshall, N. B., Andrus, S. B. \& Mayer, J. (1957). Amer. F. Physiol. 189, 343.

Miller, A. T. \& Blyth, C. S. (1953). F. appl. Physiol. 5, 3 I I.

Moulton, C. R. (1916). F. biol. Chem. 24, 299.

Mulinos, M. G. \& Pomerantz, L. (1940). F. Nutr. 19, 493.

Munro, H. N. (195I). Physiol. Rev. 3I, 449.

Pace, N. \& Rathbun, E. N. (I945). F. biol. Chem. 158, $68_{5}$.

Passmore, R., Strong, J. A. \& Ritchie, F. J. (1958). Brit. F. Nutr. 12, x13.

Peters, J. P. \& Mann, E. B. (1948). F. clin. Invest. 27, 397.

Pitts, G. C. (1956). Amer. F. Physiol. 185, 41.

Pitts, G. C. (1957). Fed. Proc. 16, Iог.

Reh, H. (1953). Virchows Arch. 324, 234.

Reiner, L., Mazzoleni, A. \& Rodriguez, F. L. (1955). Arch. Path. (Lab. Med.), 60, 369.

Ries, W. (1958). Z. ges. inn. Med. 13, 395.

Rivero-Fontan, J., Paschkis, K. E., West, E. \& Cantarow, A. (1952). Endocrinology, 5r, 100.

Rony, H. R. (1940). Obesity and Leanness. Philadelphia: Lea and Febiger.

Rossier, P. H. (195 I). Helv. med. acta, 18, $26 \mathrm{r}$.

Ryan, R. J., Williams, J. D., Ansell, B. M. \& Bernstein, L. M. (r957). Metabolism, 6, 365.

Shock, N. W. (1955). Ciba Foundn Colloq. r, 206.

Skanse, B. \& Hedenskog, I. (1957). Nord. Med. 58, 1490.

Starr, P., Petit, D. W., Chaney, A. L., Rollman, H., Aiken, J. B., Jamieson, B. \& Kling, J. (I950). F. clin. Endocrin. ro, 1237 .

Steele, J. M., Brodie, B. B., Messinger, W. J., Soberman, R. J., Berger, E. Y. \& Galdston, M. (I949).

Trans. Ass. Amer. Phycns, 52, 214.

Stephens, D. J. (194I). F. clin. Endocrin. r, 257.

Stiller, R. (1954). Med. Mschr. 8, 3 ro.

Talbot, F. B., Wilson, E. B. \& Worcester, J. (1937). Amer. F. Dis. Child. 53, 273. 
Venkatachalam, P. S., Scrikantia, S. G. \& Gopalan, C. (1954). Metabolism, 3, 138.

von Döbeln, W. (1956). Acta Physiol. scand. 37, Suppl. 126.

Wahlberg, J. (1935). Acta med. scand. 84, 550.

Wedgwood, R. J., Bass, D. E., Klimas, J. A., Kleeman, C. R. \& Quinn, M. (1953). F. appl. Physiol. 6, 317.

Wild, C., Scazziga, B. R. \& Reymond, C. (1955). Helv. med. acta, 22, 540.

Williams, R. H. (1948). $\mathscr{F}$. clin. Endocrin. 8, 257. 